\title{
Investigation of drying characteristics in superheated steam drying of UF-impregnated Chinese fir
}

\author{
Yun $\mathrm{Li}^{1} \cdot$ Xianjun $\mathrm{Li}^{1} \cdot$ Peng Quan ${ }^{1} \cdot$ Xiyi Cheng ${ }^{1} \cdot \mathrm{Xia} \mathrm{He}^{1} \cdot \mathrm{Qunying} \mathrm{Mou}^{2}$
}

Received: 12 January 2017 / Published online: 15 November 2017

(c) The Author(s) 2017. This article is an open access publication

\begin{abstract}
Urea formaldehyde (UF) resin-impregnated Chinese fir (Cunninghamia lanceolata (Lamb.)Hook.) was dried at different temperatures in an atmospheric pressure superheated steam dryer. Drying characteristics, moisture content, drying rate, temperature profile, drying defects, and color change were investigated. The moisture content was reduced from 66.21 to $11.79 \%$ within $30 \mathrm{~h}$ without causing severe drying defects; in contrast, the conventional hot air process required 7-8 days. After $25 \mathrm{~h}$ of drying, the temperatures at both the center and the surface of wood remained stable. After $34.5 \mathrm{~h}$, the surface temperature gradually approached the steam temperature. The color of the superheated steam dried Chinese fir appeared slightly more intense yellow and red than the control. Investigation of the UF-impregnated Chinese fir wood by scanning electron microscopy (SEM) revealed that the majority of the lumens and voids, including the microvoids in wood structure, was filled with urea formaldehyde resin.
\end{abstract}

\section{Introduction}

The major concerns in timber are variations in final moisture content (MC), drying rate, warp, internal and surface checking, and discoloration. Wood from fast growing plantation forests shows variations in these properties. Defects in drying are a result of using juvenile wood, which is a serious problem. Presently, the conventional method of drying uses hot, moist air as the drying medium. Extensive research is being carried out to obtain optimum drying schedules by manipulating the temperature, humidity, and velocity of the air. After several days of drying, a mist of water droplets is introduced into the drying chamber and is circulated using fans. This method helps to distribute the moisture evenly and reduce moisture stress by temporarily increasing the relative humidity inside the chamber. If the temperature of the dryer is too high, the internal moisture stress may lead to cracking, due to large gradation in moisture content within the board (Kretschmann and Green 1996; Yi et al. 2004; Matan

Yun Li

1xjmu@163.com

1 Material Science and Engineering College, Central South University of Forestry and Technology, 410004 Changsha, Hunan, China

2 College of Science, Central South University of Forestry and Technology, 410004 Changsha, Hunan, China and Kyokong 2002). The drying time varies from 7 to 16 days, depending on the thickness of the lumber. Rapid drying leads to drying defects, whereas slower drying increases the operational costs.

Wood drying is one of the most important steps in solid wood processing. To the best of the authors 'knowledge, most of the relevant research concerned with wood products such as UF-resin impregnated Chinese fir plywood or some artifacts, the drying behavior of Chinese fir wood modified by UF resin has not been extensively studied. Superheated steam drying has gained tremendous interest in industrial applications such as drying of paper, food products, and coal. Earlier studies have illustrated some advantages of steam drying (Stubbing 1999; Chen et al. 2000; Pang and Pearson 2007), which include high drying rates in the case of both, constant and falling periods, as well as deodorization (Ratnasingam and Grohmann 2015). At a very high drying temperature, the wood temperature is above the boiling point of water $\left(100{ }^{\circ} \mathrm{C}\right)$, which significantly enhances the flow of moisture in the wood interior (Tarnawski et al. 1996; Aly 1999; Vazquez et al. 2001; Bekhta and Niemz 2003). Pang and Dakin (1999) studied the drying rates and temperature profiles for both superheated steam vacuum drying and moist air-drying of softwood lumber (Pinus radiata), finding that superheated steam produced a significantly faster drying effect than hot moist air. Compared with conventional kiln drying, superheated steam drying has the potential to 
improve the quality of wood and to reduce energy consumption. The use of superheated steam for drying stimulates continuous heating, alleviating the need for alternative heating (Alverez Noves and Fernandez-Golfin 1994). Another benefit of superheated steam drying is that evaporated steam is exhausted and condenses during the process (Yang et al. 2013), whereas in conventional hot air drying, the exhausted hot air undergoes heat loss due to drying.

The main objectives of the present work were to study the utilization of superheated steam for drying urea formaldehyde (UF) resin-impregnated Chinese fir and to investigate the drying characteristics in terms of instant drying rates and temperature profiles. This research provides a better understanding of drying characteristics of superheated steam and explains how drying medium influences the drying qualities. The drying characteristics of superheated steam drying were compared with those of hot air, aiming at promoting the transfer of drying technology from research into manufacturing practice.

\section{Materials and methods}

\subsection{Materials}

Fresh Chinese fir (Cunninghamia lanceolata (Lamb.) Hook) timber was collected from the Jiangxi Province, China for wood sample and was then impregnated with urea formaldehyde resin (molecular weight $8000 \mathrm{Da}$, solid content 25\%). The Chinese fir was 13 years of age, had a diameter of $12.3 \mathrm{~cm}$ at breast height set to $1.5 \mathrm{~m}$, and was characterized by an initial average moisture content (MC) of $78 \%$. The fabrication of UF-modified wood was prepared in a pressure-processing tank. The vacuum pressure of the impregnation tank remained at $0.08 \mathrm{MPa}$ for $20 \mathrm{~min}$, then the specimens were added into the UF resin solution in the impregnation tank at a pressure of $0.6 \mathrm{MPa}$ for $2 \mathrm{~h}$. In parallel, the untreated group was kiln-dried until a target moisture content of $15 \%$. Prior to use, the untreated and UF-modified timber were cut into the following dimensions: $200 \mathrm{~mm}$ (longitudinal $) \times 100 \mathrm{~mm}$ (tangential) $\times 20 \mathrm{~mm}$ (radial). Only the samples presenting a normal color with a straight grain and no knots were selected for this experiment. The specimens were divided into two groups (6 replicates per group): the impregnated and the untreated group.

\subsection{Drying characterization}

The samples were checked for drying defects including end checks, end-to-surface checks, and surface checks at fixed time intervals during the drying process by visual appearance. Figure 1 is a schematic representation of the experiment using the superheated steam drying procedure. There are two temperatures and two mass flows associated with any portion of the wood area: superheated steam temperature of the inlet $\left(T_{i}\right)$ and mass flow of the inlet $\left(F_{i}\right)$; and superheated steam temperature $\left(T_{o}\right)$ of the outlet and mass flow of the outlet $\left(F_{o}\right)$.

During drying at $120,130,140$, and $150{ }^{\circ} \mathrm{C}$ using superheated steam (flow rate of $125 \mathrm{~m}^{3} / \mathrm{min}$ ), sample weights and wood temperatures were continuously measured and recorded. The drying procedure was continued until the moisture content of the wood was below $12 \%$. The samples were periodically weighed on a meter balance (accuracy of \pm 0.005 ). Temperatures were recorded from a digital reader, as shown in Fig. 2a. Thermocouples were placed at the surface and at the center of wood specimens to obtain the constant temperature profile recordings, as shown in Fig. 2 b.

The drying rate for the sample was obtained by measuring the weight of the wood board after each period of drying. The initial moisture content of the wood was calculated by cutting out a small portion of the board and drying it at $103{ }^{\circ} \mathrm{C}$ for $48 \mathrm{~h}$.

\subsection{Color change}

Color changes of the samples dried using superheated steam at different temperatures and by conventional hot air drying were determined using color difference meter (WCS-S, NH310, $\Phi 20$ mm, Abarke Technology, Tianjin, China). The colors were represented as " $a$ *", " $b$ " " and " $L$ " " values in the Hunter system (Vanclay et al. 2009). " $L^{*}$ " represents the lightness, " $a$ *" represents the chromatic coordinates on red-green axis, and " $b$ " represents chromatic coordinates
Fig. 1 Schematic representation of the superheated steam drying procedure
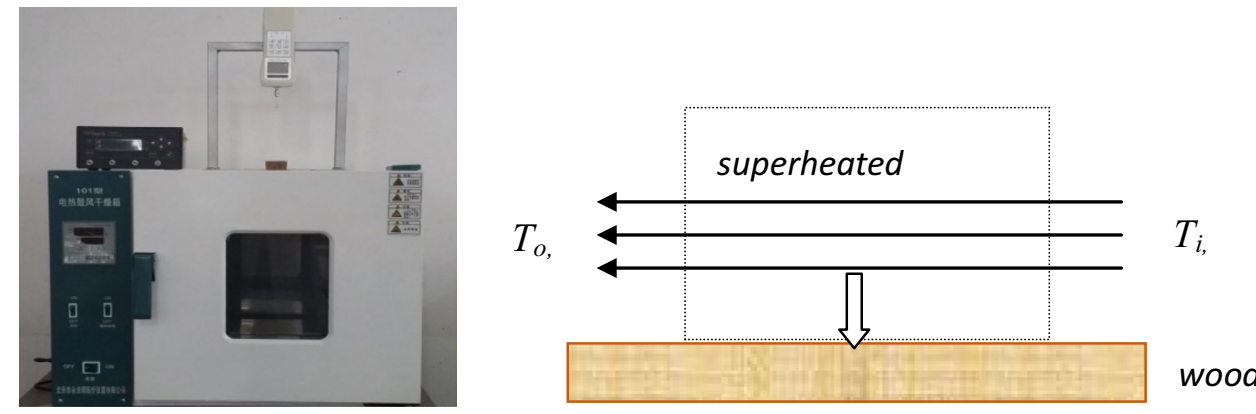


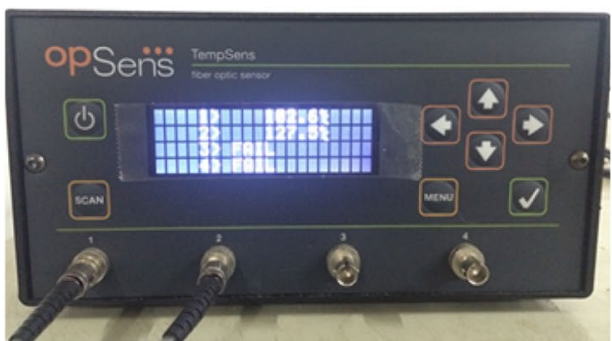

(a)

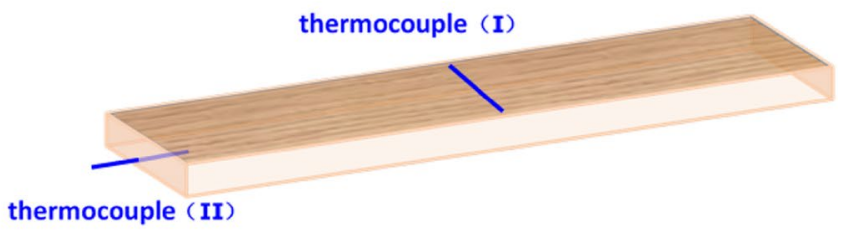

(b)

Fig. 2 a Temperature reader and $\mathbf{b}$ locations on the sample at which the thermocouples were placed: surface (I) and center (II)

on blue-yellow axis. The net change of color $(\Delta E)$ was calculated by the following equation (Eq. 1),

$\Delta E=\left[\Delta L^{* 2}+\Delta a^{* 2}+\Delta b^{* 2}\right]$,

where $\Delta L$ is the difference in lightness, $\Delta a$ and $\Delta b$ are the differences in red-green coordinates and blue-yellow coordinates, respectively.

Scanning electron microscopy (SEM) was used to study the depth and uniformity of penetration of the UF resin inside the impregnated Chinese fir. The internal structure and radial wall were also examined. The dried samples were cut into small specimens by using a sliding microtome (Leika, ESM-100L, Japan) to obtain a size of $10 \mathrm{~mm} \times 10$ $\mathrm{mm} \times 5 \mathrm{~mm}$ (longitudinal $\times$ radial $\times$ tangential) for the SEM observations. The specimens were mounted on aluminum stubs, sputter coated, and analyzed on microscope (Questar, 450 Quanta $^{\mathrm{TM}}$, Hillsboro, USA) operating at an accelerating voltage of $15 \mathrm{kV}$.

\section{Results and discussion}

\subsection{SEM}

Samples for SEM were cut from the sample center to study the penetration and distribution of the UF resin within the wood sample, as previously described (Bolton et al. 1988). SEM images of radial walls of the control and specimens on the cross direction subjected to superheated steam drying at $120,130,140$, and $150{ }^{\circ} \mathrm{C}$ are shown in Fig. 3. The

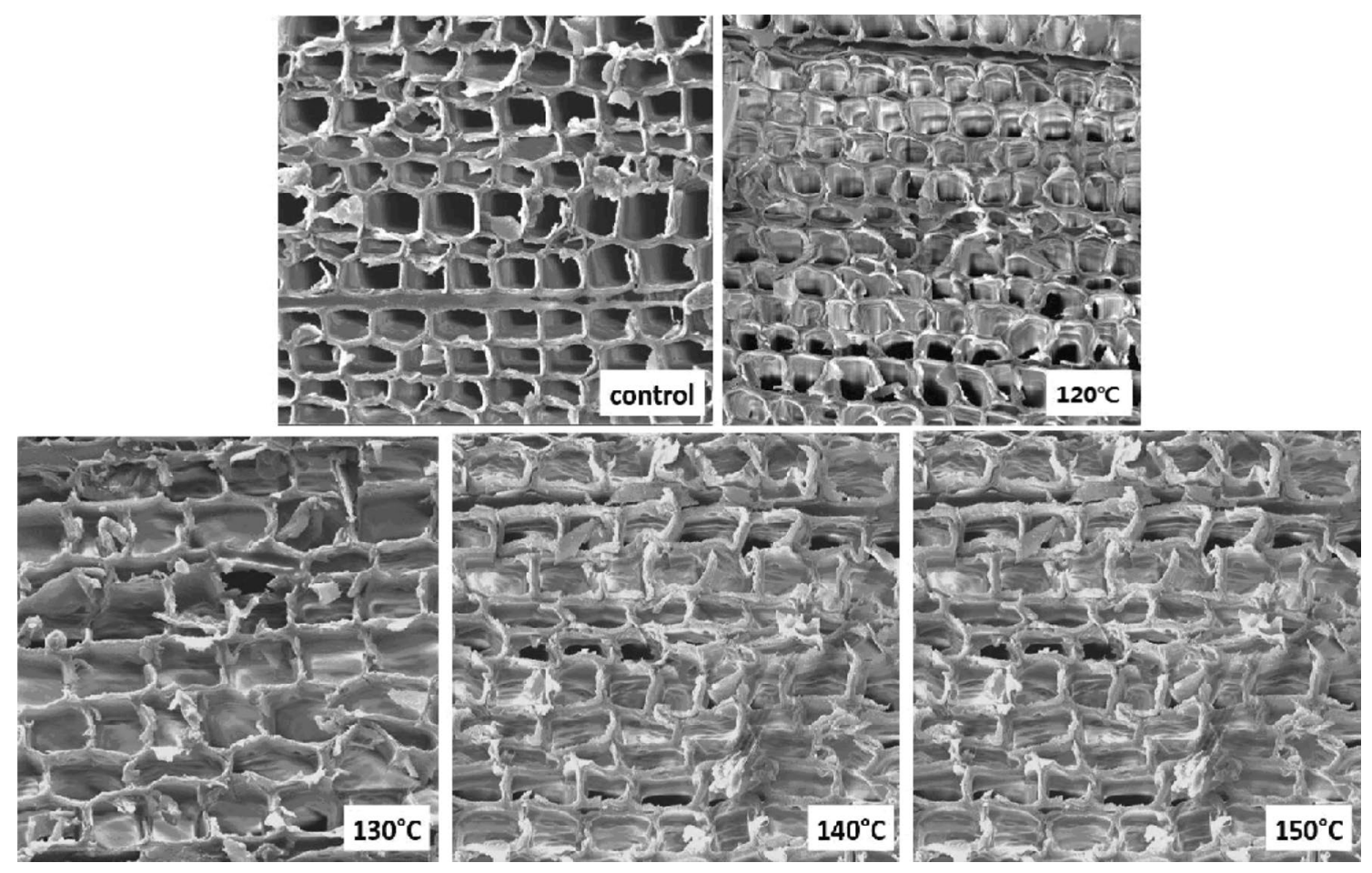

Fig. 3 SEM images of the control and UF-impregnated Chinese fir subjected to superheated steam drying at different temperatures 
majority of the lumens and voids, including the microvoids in the wood structure, were filled with urea formaldehyde resin. This observation suggested that pressure impregnation successfully replaced the interior water molecules with the resin and produced a satisfactory bulking effect. The resin penetrated the cell walls, lumens, and intercellular spaces of wood, with maximum penetration in the cell walls.

\subsection{Drying defects}

During drying, three main types of drying defects (initial checks, internal checks, and cross-sectional deformations) were recorded and are listed in Table 1. The numbers in the table (in the initial check and internal check columns) signify the drying defects rank. Almost every sample had light end checks in initial stages. As the tests proceeded, the end checks became larger, and some of them transformed into end-to-surface checks and surface checks. Subsequently, checks kept developing until the moisture content was reduced to approximately $30 \%$. After reaching a moisture content of $30 \%$, these initial checks stopped stretching and began to cure, and the end checks closed in later stages.

\subsection{Color change}

In addition to drying defects, color changes during the drying of Chinese fir were also considered. In general, the Chinese fir underwent a change in its color either due to fungal

Table 1 Drying defects after superheated steam drying

\begin{tabular}{llll}
\hline $\begin{array}{l}\text { Drying defects } \\
\left({ }^{\circ} \mathrm{C}\right)\end{array}$ & Initial check & $\begin{array}{l}\text { Internal } \\
\text { check }\end{array}$ & $\begin{array}{l}\text { Cross-sectional } \\
\text { deformation }(\mathrm{mm})\end{array}$ \\
\hline 120 & 1 & 1 & 0.54 \\
130 & 1 & 1 & 0.60 \\
140 & 3 & - & 0.99 \\
150 & 2 & - & 1.07 \\
\hline
\end{tabular}

attack or due to oxidation during conventional drying. Pure steam, devoid of oxygen, provided an inert atmosphere during the superheated steam drying process in the dryer, which prevented the oxidation of wood, which minimized the chances of oxidation and helped to retain the color of dried wood similar to fresh wood. Table 2 presents the colors and lightness values of the superheated steam dried UF-impregnated Chinese fir samples (tangential direction) and the control group. The values of $a^{*}, b^{*}$, and $L^{*}$ at the beginning of the experiment were $-0.33,-1.13$, and 33.14 , respectively. The $L^{*}$ values of the samples subjected to superheated steam drying were slightly lower than the control, whereas the values of $a^{*}$ and $b^{*}$ increased. However, the net changes in product color $(\Delta E)$ were not remarkable for samples dried at $120,130,140$, and $150{ }^{\circ} \mathrm{C}$. The values for net color changes were slightly higher than those of untreated ones. This result implied that the dried Chinese fir showed slightly more intense yellow and red colors after superheated steam drying compared with untreated Chinese fir.

\subsection{Drying rates}

The moisture contents of the samples in superheated steam drying experiments at the temperatures of 120,130, 140, and $150{ }^{\circ} \mathrm{C}$ are shown in Fig. 4. The results suggested remarkably lower moisture contents of the samples at higher superheated steam drying temperatures at corresponding time intervals. Generally, the curves depicting drying consisted of three distinct periods: (1) initial heating period; (2) constant drying period; and (3) falling rate period. The initial period, characterized by a rapid increase in temperature of the wood from room temperature to $100{ }^{\circ} \mathrm{C}$, could not be clearly seen in this figure, as this time frame was small compared with the total drying time.

The drying periods for reducing the moisture content to ideally $12 \%$ were approximately $44.5,36.5,35.5$, and $28.5 \mathrm{~h}$ for superheated steam temperatures of 120, 130, 140, and $150{ }^{\circ} \mathrm{C}$, respectively. Although at $150{ }^{\circ} \mathrm{C}$ the drying period
Table 2 Color changes and values of $L^{*}, a^{*}$, and $b^{*}$ for superheated steam dried samples at different temperatures

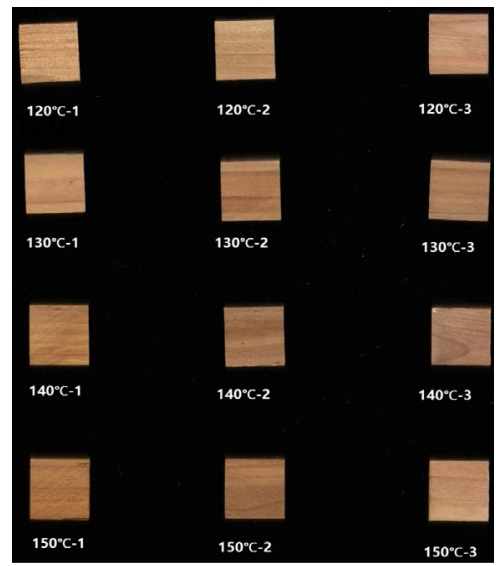

\begin{tabular}{ccccc}
\hline Samples & $L^{*}$ & $a^{*}$ & $b^{*}$ & $\square E$ \\
\hline $120^{\circ} \mathrm{C}$ & 41.93 & 6.97 & 14.85 & 19.6 \\
$130^{\circ} \mathrm{C}$ & 42.32 & 6.07 & 14.57 & 19.3 \\
$140^{\circ} \mathrm{C}$ & 41.00 & 6.06 & 15.02 & 19.1 \\
$150^{\circ} \mathrm{C}$ & 42.87 & 5.67 & 13.53 & 18.3 \\
Control & 43.71 & 5.72 & 12.52 & 18.6 \\
\hline
\end{tabular}

Mean values from 200 measurements. 


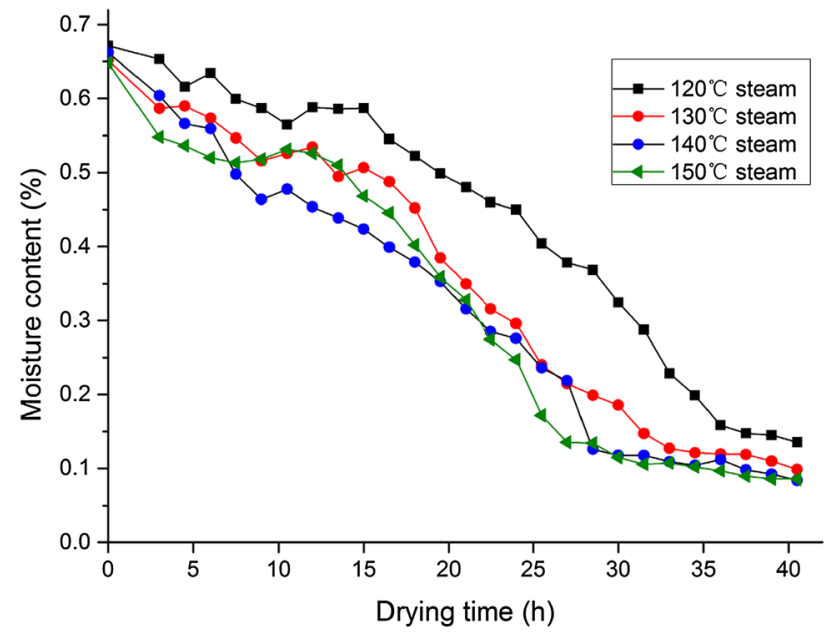

Fig. 4 Moisture content of samples dried using superheated steam at different temperatures

for reducing the moisture content to the desired level was the shortest, it was not preferred because its surface color deteriorated (slightly brown), and the drying defects (especially initial and internal checks) were severe. The drying time for reducing the moisture content to the desired level is approximately $70 \mathrm{~h}$ at a temperature of $120^{\circ} \mathrm{C}$ in conventional hot air drying (Pang and Dakin 1999). Thus, there was a $36.43 \%$ reduction of drying time by using superheated steam instead of conventional hot air at the same temperature.

Figure 4 shows that the drying rates of superheated steam were much higher than hot air, which took 7 to 8 days to reduce the moisture content of the wood to the acceptable value of less than 15\% (Pang 1996, 2000). This was due to the impingement process (Peng et al. 2012), which caused rapid heat transfer to the wood surface and stimulated a quick loss of moisture ( $\mathrm{Li}$ et al. 1999; Ishikawa et al. 2004). However, hot air drying at a constant rate gave faster results than that of superheated steam, due to lower humidity inside the chamber. After $28 \mathrm{~h}$ of superheated steam drying at $120^{\circ} \mathrm{C}$, the rate of water loss from the dried sample was quite low, due to a large quantity of water vapor present inside the chamber. Because the rates of water vapor leaving the vent and vapor condensing into liquid water were lower than that entering it, the internal humidity remained relatively high. This made the removal of bound water somewhat difficult. Hence, it was necessary to reduce the humidity inside the chamber to further reduce the final moisture content of impregnated wood.

Figure 5 compares the drying rates of wood samples using superheated steam and hot air conditioning. Initially, in both cases, the drying rates were relatively high because of the high concentration of water in the cells of wood present at the surface, thus allowing water to be removed readily. The drying rate decreased almost linearly as the moisture

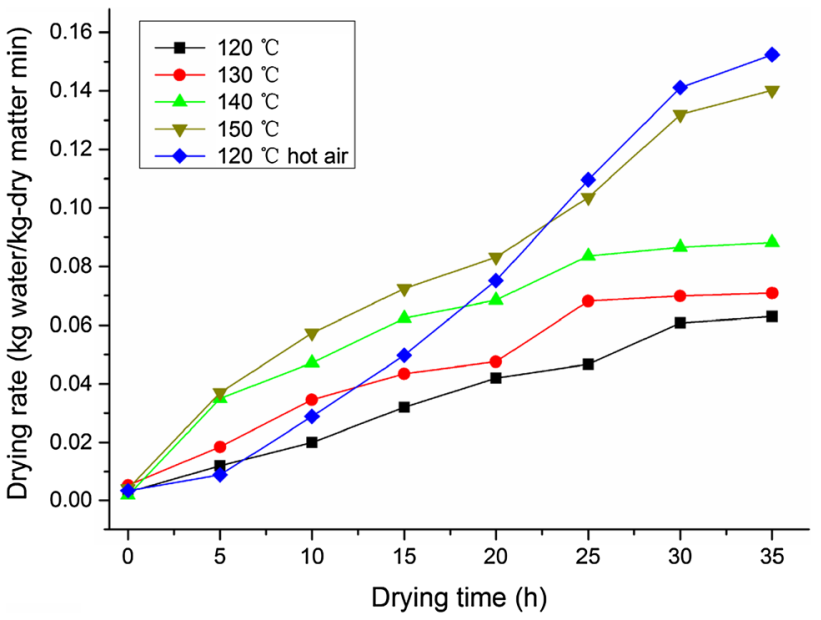

Fig. 5 Drying rates of superheated steam drying and hot air drying processes

content decreased. As the temperature of the drying process approached the boiling point $\left(100^{\circ} \mathrm{C}\right)$, the drying rate was lower for superheated steam than for hot air. The drying rate of superheated steam at $120{ }^{\circ} \mathrm{C}$ was $0.02 \mathrm{~kg}$ water/ $(\mathrm{kg}$ of dry matter min) with $51.82 \% \mathrm{MC}$, which was less than that of the hot air under similar conditions. However, the drying rates at $150{ }^{\circ} \mathrm{C}$ for steam and hot air were 0.07 and $0.05 \mathrm{~kg}$ water/(kg dry of matter min), respectively, with $42.35 \%$ MC. Based on these findings, superheated steam was more capable of removing water at higher temperatures, and the overall drying rates in the superheated steam were noticeably improved.

\subsection{Wood Temperature}

Figure 6 shows temperature profiles at the center and on the surface of the wood, which was dried at different steam temperatures. As mentioned earlier, the temperature in each group increased rapidly until the boiling point of water was reached. It was also clear that the temperature at the surface increased at a faster rate than at the center. The temperature at the surface reached $100{ }^{\circ} \mathrm{C}$ after $24.0,18.0,16.5$, and $15.0 \mathrm{~h}$ at $120,130,140$, and $150{ }^{\circ} \mathrm{C}$, respectively, while at the center it took approximately $25.5,21.0,18.0$, and $16.5 \mathrm{~h}$ to reach the same temperature.

Furthermore, after $25 \mathrm{~h}$ of drying, the temperatures at both the center and surface remained stable (slightly lower than the steam temperature). After $34.5 \mathrm{~h}$ of drying, the temperature at the surface gradually approached the steam temperature, which indicated that the water molecules were tightly bound to the cell walls of wood from the UF-impregnated Chinese fir.

In the superheated steam drying method, internal resistance for vapor movement was less than the hot moist air 


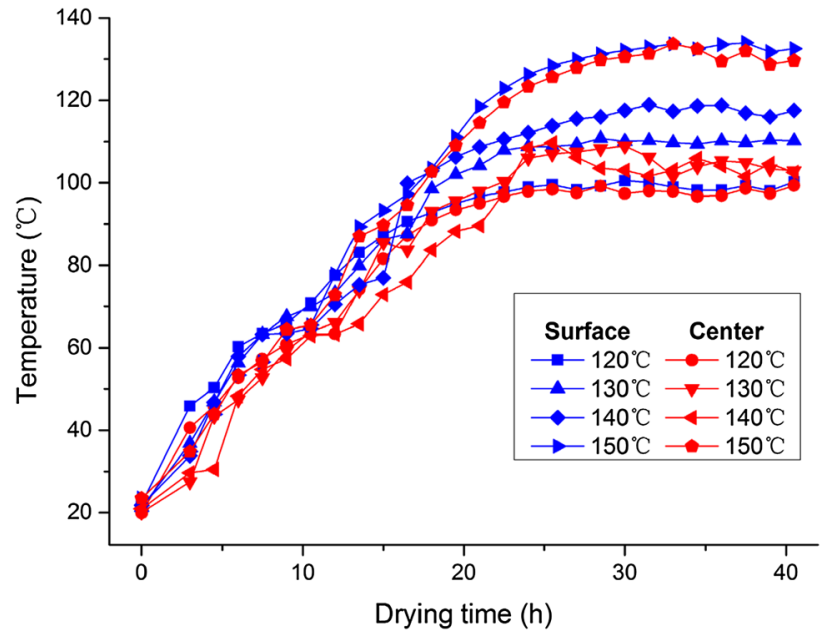

Fig. 6 Temperatures at the center and at the surface of wood for superheated steam drying method

drying method, particularly at temperatures below $100{ }^{\circ} \mathrm{C}$. Therefore, the surface of the wood board was expected to retain relatively high moisture content over a long period of time, during which the board dried at a constant rate. Because external mass-transfer in steam drying was much faster than that in hot air, the driving force for the moisture transfer (such as the difference in partial vapor pressure) was lower than that for the hot air when dried at the same rate (Schwartze and Brocker 2000; Thiam et al. 2002). In this manner, the surface of the board remained at a lower temperature. The lower surface temperature was not effective in increasing the heat supply (Pang 1997). However, it was successful in reducing the severe drying defects such as internal checking and discoloration to brownish stain.

The predicted drying schedule below $150{ }^{\circ} \mathrm{C}$ was applied to verify the process experimentally using a $2 \mathrm{~m}^{3}$ dryer. Finally, the drying characteristics (warp, internal checks and cross-section deformations, and drying velocity) of the UF resin-impregnated wood were in good agreement with the drying characteristics recorded when using the sawn timber standard (GB/T 6491-2012 2012), which requires the minimum drying grade as being second rank. In the practical drying process, a moisture detector would be inserted inside the timber to continuously record the moisture changes, providing the evolution of the drying stage. Therefore, this drying schedule is moisture-based.

\section{Conclusion}

Drying in an atmospheric pressure superheated steam dryer was carried out to study the drying characteristics of UFimpregnated Chinese fir. The drying characteristics, such as moisture content, drying rate, temperature profile, defects, and color change were investigated.

SEM showed that a majority of the lumens and voids within the wood structure were either filled and/or covered with UF resin. The drying time could be reduced remarkably by using superheated steam, without causing severe drying defects. Drying time could be reduced from 7 to 8 days to less than 2 days, which would considerably reduce the operational costs. After $25 \mathrm{~h}$ of drying, temperatures at both the center and the surface remained stable. After $34.5 \mathrm{~h}$, the surface temperature gradually approached the temperature of the steam.

Moreover, the wood color was not remarkably affected by superheated steam drying. There was no apparent color difference, and the values of the net color change $\Delta \mathrm{E}$ for the treated samples were slightly higher than the control group. Further studies are needed to clarify the role of UF resin in superheated drying process.

Acknowledgements This project was funded by the National "Twelfth Five-Year" Plan for Science and Technology (no. 2015BAD14B01) and the 948 Project in the State Bureau of Forestry (no. 2014-4-50).

Open Access This article is distributed under the terms of the Creative Commons Attribution 4.0 International License (http://creativecommons.org/licenses/by/4.0/), which permits unrestricted use, distribution, and reproduction in any medium, provided you give appropriate credit to the original author(s) and the source, provide a link to the Creative Commons license, and indicate if changes were made.

\section{References}

Alverez Noves H, Fernandez-Golfin Seco JI (1994) Practical evaluation and operation of superheated steam drying process with different softwoods and hardwoods. Holz Roh-Werkst 52:135-138

Aly SE (1999) Energy efficient combined superheated steam dryer/ MED. Appl Therm Eng 19(6):659-668

Bekhta P, Niemz P (2003) Effect of high temperature on the change in color, dimensional stability and mechanical properties of Spruce wood. Holzforschung 57(5):539-546

Bolton AI, Dinwoodie JM, Davies DS (1988) The validity of the use of SEM/DAX as a tool for the detection of UF resin penetration into wood cell walls in particle board. Wood Sci Technol 22(4):345-356

Chen Z, Wu W, Agarwal PK (2000) Steam-drying of coal. Part 1. Modeling the behavior of a single particle. Fuel 79(8):961-973

GB/T 6491 - 2012 (2012) Drying quality of sawn timber B69. Chinese National Standard, Beijing

Ishikawa A, Kuroda N, Kato AJ (2004) In situ measurement of wood moisture content in high-temperature steam. Wood Sci 50:7

Kretschmann DE, Green DW (1996) Modeling moisture contentmechanical property relationships for clear Southern Pine. Wood Fiber Sci 28(3):320-337

Li YB, Seyed-Yagoobi J, Moreira RG, Yamsaengsung R (1999) Superheated steam impingement drying of tortilla chips. Dry Technol 17(1\&2):191-213

Matan N, Kyokong B (2002) Effect of moisture content on some physical and mechanical properties of juvenile rubberwood 
(Hevea brasiliensis Muell. Arg.). Songklanakarin J Sci Technol 25(3):327-340

Pang S (1996) Development and validation of a kiln-wide model for drying of softwood lumber. In: Proceedings of 5th international IUFRO wood drying conference, Skelleftea, Sweden, pp 103-110

Pang S (1997) Some consideration in simulation of superheated steam drying of softwood lumber. Dry Technol 15(2):651-670

Pang S (2000) Drying of sapwood, heartwood and mixed sapwood and heartwood boards of Pinus radiate. Holz Roh-Werkst 58(5):363-367

Pang S, Dakin M (1999) Drying rate and temperature profile for superheated steam vacuum drying and moist air drying of softwood lumber. Dry Technol 17(6):1135-1147

Pang S, Pearson H (2007) Application of superheated steam drying technology for softwood timber. Dry Technol 9(9):2079-2094

Peng Y, Li F, Yang F, Yi S-1 (2012) Effect of steam pretreatment on wood moisture content and characteristics of vacuum drying. For Stud China 14:315

Ratnasingam J, Grohmann R (2015) Superheated steam application to optimize the kiln drying of rubberwood (Hevea brasiliensis). Eur J Wood Prod 73:407-409
Schwartze JP, Brocker SA (2000) Theoretical explanation for the inversion temperature. In: Proceedings of the 12th international drying symposium, Noordwijkerhout, Netherlands, pp 1-10

Stubbing TJ (1999) Airless drying-developments since IDS 94. Dry Technol 17(7\&8): 1639-1651

Tarnawski WZ, Mitera J, Borowski P, Klepaczka A (1996) Energy analysis on use of air and superheated steam as drying media. Dry Technol 14(7\&8):1733-1749

Thiam M, Milota MR, Leichti RJ (2002) Effect of high-temperature drying on bending and shear strengths of Western Hemlock lumber. For Prod J 52(4):64-68

Vanclay JK, Henson M, Palmer G (2009) Color variation and correlations in Eucalyptus dunnii sawnwood. J Wood Sci 54(6):431-435

Vazquez G, Chenlo F, Moreira R (2001) Modeling of desorption isotherms of chestnut: influence of temperature and evaluation of isosteric heats. Dry Technol 19(6):1189-1200

Yang J, Wei HB, Li F, Yi S-1 (2013) The effect of high-pressure and high-temperature drying treatments on the deresination ratio of Pinus massoniana. For Sci Pract 15:76

Yi S, Zhang B, Chang J, Du C (2004) Drying characteristics of wood under vacuum-superheated steam. For Stud China 6:41 